\title{
Penerapan Metode Activity Based Costing dalam Menentukan Harga Pokok Produksi Karet PT. Sumber Djantin Sambas
}

\author{
Gowardy* \\ Universitas Tanjungpura \\ Handi Brata \\ Universitas Tanjungpura
}

\begin{abstract}
This study aims to understand how to allocate overhead cost in rubber-processing factory of PT. Sumber Djantin Sambas using Activity-Based Costing method. Furthermore, this research also attempts to compare the allocation results of the existing costing systems in PT. Sumber Djantin Sambas with those created through Activity-Based Costing systems. To accomplish these objectives, this study applies case study method. The main sources of data come from interview transcript and cost and financial documents. This study results show that the cost of goods manufactured for product SIR 20 and compound rubber are overcosted. Between these two products, SIR 20 is more overcosted. The total overcosting of these two products reaches $\mathrm{Rp}$ 2.749.997.488,57. Using Activity Based Costing, company can allocate the costs more accurately and reduce the distortion effect of costs which is caused by traditional overhead allocation method.
\end{abstract}

Keywords: Activity Based Costing, Harga Pokok Produksi, Perusahaan Karet, Alokasi Biaya Overhead

\section{PENDAHULUAN}

Industri perkebunan dan pengolahan hasil alam berkembang lumayan pesat di Indonesia saat ini. Hal ini terlihat dari banyaknya perusahaan-perusahaan lokal yang berhasil menembus pasar internasional, baik yang berupa perusahaan berskala kecil maupun yang berskala besar. Adapun komoditi-komoditi perkebunan yang menjadi andalan dalam perdagangan internasional adalah rempah-rempah, kelapa sawit dan karet. Provinsi Kalimantan Barat (Kal-Bar), secara khusus, merupakan daerah penghasil kelapa sawit dan karet. Dua komoditi ini dapat tumbuh subur dikarenakan iklim dan kondisi tanah yang mendukung pertumbuhan kedua jenis tanaman ini. Selain itu lahan perkebunan yang masih luas juga sangat mendukung untuk membudidayakan kedua jenis tanaman ini.

\footnotetext{
* Korespendensi: Gowardy, Alumnus Jurusan Akuntansi, Fakultas Ekonomi, Universitas Tanjungpura, Jalan Prof. Dr. H. Hadari Nawawi, Pontianak, Indonesia. Email: gowardy2@gmail.com
} 
Potensi yang ada tentunya menarik perhatian para pebisnis untuk mendirikan usaha dalam bidang pengolahan komoditi tersebut. Salah satu contohnya adalah PT Sumber Djantin Sambas yang menjadi perusahaan kasus dalam penelitian ini. PT. Sumber Djantin Sambas merupakan perusahaan pengolahan karet mentah menjadi crumb rubber dengan 2 (dua) jenis produk unggulannya, yaitu SIR 20 (Standard Indonesia Rubber) dan Compound Rubber. Dalam proses pengolahannya, PT. Sumber Djantin Sambas menggunakan bahan baku karet lokal, tenaga kerja lokal serta sejumlah mesin pengolah.

Untuk kebutuhan pelaporan biaya, PT. Sumber Djantin Sambas selama ini mempergunakan metode alokasi biaya tradisional, yang terlihat pada cara pembebanan biaya bahan baku dan biaya tenaga kerja yang dilakukan secara langsung ke produk sedangkan untuk pembebanan biaya overhead pabrik dilakukan berdasarkan kuantitas produk yang dihasilkan dalam satuan kilogram. Selain itu, pembebanan biaya overhead juga didasarkan pada kuantitas produk yang dihasilkan, tanpa memisahkan antara produk SIR 20 dan produk Compound Rubber. Tentunya alokasi overhead demikian menimbulkan pertanyaan mengenai keakuratan perhitungan biaya dan harga pokok produksi yang dimiliki perusahaan selama ini karena ketergantungan pada pemicu biaya (cost drivers) berbasis volume sebagai satu-satunya dasar alokasi biaya overhead dapat menimbulkan distrosi biaya produk (Atkinson, Kaplan, Matsumura \& Young, 2012; Panggiarti, 2010). Ini mendorong penulis untuk mempelajari lebih lanjut sistem alokasi biaya di PT. Sumber Djantin Sambas.

Biaya overhead PT. Sumber Djantin Sambas juga didominasi oleh biaya-biaya yang timbul akibat penggunaan mesin dalam berproduksi. Hal ini terjadi karena dalam proses pengolahan, penggunaan mesin dapat memperlancar dan meningkatkan efisiensi kegiatan produksi. Namun, di lain pihak, penggunaan mesin dalam produksi memicu penambahan biaya-biaya non-unit level, yaitu biaya-biaya yang kenaikan/penurunannya tidak dipengaruhi oleh perubahan jumlah unit yang diproduksi. Menurut Hilton \& Platt (2015), perusahaan yang memiliki banyak aktivitas yang terkategori dalam aktivitas nonunit level, seperti aktivitas permesinan, cenderung mengalami distorsi biaya jika perusahaan tersebut menerapkan metode tradisional dalam alokasi biaya overhead.

Oleh karena itu, dalam rangka mengalokasikan biaya secara lebih akurat dan efektif, metode Activity Based Costing ( $A B C$ ) dapat menelusuri biaya-biaya overhead lebih detail dan menyeluruh sehingga harga pokok produksi tidak mengalami overcosted maupun undercosted (Martusa \& Adie, 2011). memberikan ketepatan hasil alokasi. Namun, sampai dengan penelitian ini dibuat, manajemen perusahaan PT. Sumber Djantin Sambas belum menerapkan metode Activity Based Costing. Berdasarkan pertimbanganpertimbangan ini, penelitian ini diarahkan untuk mengetahui berapa harga pokok produksi produk SIR 20 dan produk Compound Rubber jika alokasi biaya overhead dilakukan dengan menggunakan sistem Activity Based Costing dan untuk mengetahui perbedaan yang timbul antara sistem alokasi biaya yang diterapkan pada PT. Sumber Djantin unit Sambas dengan sistem alokasi menggunakan Activity Based Costing. 


\section{TINJAUAN PUSTAKA}

\subsection{Definisi Biaya Produk dan Komponennya}

Biaya produksi adalah biaya yang timbul akibat proses produksi barang atau penyediaan jasa kepada konsumen (Hansen \& Mowen, 2007). Pada perusahaan manufaktur, biaya tersebut dibebankan ke barang mentah yang dibeli ataupun ke barang setengah jadi yang akan diproduksi lebih lanjut untuk dijual kembali (Hilton \& Platt, 2015). Menurut Carter (2009), biaya produksi sering disebut sebagai biaya manufaktur atau biaya pabrik. Secara garis besar, biaya produksi terdiri dari biaya bahan baku, biaya tenaga kerja langsung, dan biaya overhead pabrik.

Biaya bahan baku merupakan semua biaya bahan baku yang membentuk produk akhir (Carter, 2009) dan biaya ini tidak dapat terpisahkan dari produk yang dihasilkan. Karena bahan baku menentukan hasil akhir dari suatu produk dan biaya bahan baku dapat ditelusuri langsung ke produk akhir, komponen biaya ini tidak dapat dihilangkan dari perhitungan biaya dari suatu produk (Carter, 2009). Biaya tenaga kerja langsung merupakan kompensasi dari semua pekerja pabrik yang dapat ditelusuri secara ekonomis ke objek biaya (Horngren, Datar \& Rajan, 2012). Atau dengan kata lain, biaya tenaga kerja langsung merupakan biaya yang dikeluarkan untuk membiayai tenaga kerja langsung yang diperlukan untuk mengolah bahan baku menjadi barang jadi.

Biaya overhead merupakan biaya produksi selain biaya bahan baku dan tenaga kerja langsung yang digunakan untuk mengolah bahan baku menjadi bahan jadi. Menurut Horngren, Datar \& Rajan (2012), biaya overhead pabrik mencakup semua biaya manufaktur lainnya yang tidak dapat ditelusuri langsung secara ekonomis ke produk akhir. Secara umum, biaya overhead pabrik dapat dikelompokkan menjadi 3 yaitu bahan tidak langsung, tenaga kerja tidak langsung dan biaya tidak langsung lainnya.

\subsection{Harga Pokok Produksi}

Menurut Hansen dan Mowen (2007), harga pokok produksi mencerminkan total biaya barang yang diselesaikan selama periode berjalan. Biaya yang hanya akan dibebankan ke barang yang akan diselesaikan adalah biaya manufaktur bahan langsung, biaya tenaga kerja langsung dan overhead. Rincian dari biaya ini diuraikan dalam daftar pendukung yang disebut sebagai laporan harga pokok produksi.

Pada dasarnya, harga pokok produksi merupakan penjumlahan biaya pabrik dengan barang dalam proses dikurangi dengan persediaan akhir. Harga pokok produksi kemudian akan dimasukkan ke dalam laporan rugi laba dan mempengaruhi harga pokok penjualan.

Di dalam perusahaan manufaktur, informasi mengenai harga pokok produksi sangat penting bagi manajemen perusahaan. Menurut Mulyadi (2005) manfaat informasi harga pokok produksi adalah untuk menentukan harga jual produk, memantau realisasi 
biaya produksi, menghitung laba atau rugi periodik dan menentukan harga pokok persediaan produk jadi dan produk dalam proses yang disajikan dalam neraca.

\subsection{Akuntansi Biaya Tradisonal}

Menurut Mulyadi (2003) akuntansi biaya tradisional adalah adalah akuntansi biaya yang didesain untuk perusahaan manufaktur dan yang berorientasi ke penentuan kos produk dengan fokus biaya pada tahap produksi. Akuntansi biaya tradisional mengasumsikan bahwa biaya diklasifikasikan menjadi 2 yaitu biaya tetap dan variabel. Biaya variabel sendiri berubah seiring dengan perubahan unit produksi yang terjadi. Adapun tiga unsur utama dari perhitungan biaya dengan metode tradisional adalah biaya bahan baku, biaya tenaga kerja langsung dan biaya overhead pabrik.

Biaya bahan baku dan biaya tenaga kerja langsung merupakan biaya yang dapat dialokasikan langsung ke produk karena dapat ditelusuri langsung ke produk. Sedangkan biaya overhead pabrik, dibebankan ke dalam produk berdasarkan jumlah produk yang diproduksi. Metode pembebanan ini disebut Volume Based System. Dengan metode ini, biaya overhead dianggap proporsional dengan jumlah produk yang diproduksi. Sebagai contoh apabila sebuah perusahaan membebankan biaya overhead berdasarkan jam mesin maka produk yang mengkonsumsi jam mesin lebih banyak akan mendapatkan alokasi biaya yang lebih besar. Hal ini mengakibatkan pembebanan tidak adil karena pembebanan tidak proporsional dengan komsumsi sumber daya yang sebenarnya oleh produk.

Menurut Carter (2009) pada sistem akuntansi biaya tradisional, pembebanan biaya overhead dilakukan dengan memperhatikan dasar tarif overhead dan dasar alokasi overhead. Pembebanan dilakukan dengan cara mengumpulkan biaya pada tempat penampungan biaya (Cost Pool) dan kemudian menggunakan dasar yang telah ditentukan perusahaan dengan memperhatikan faktor yang dapat mewakili biaya overhead yang akan dibebankan untuk membebankan biaya ke produk.

Akibat pembebanan biaya terhadap produk yang tidak proporsional dengan konsumsi sumber daya, sistem akuntansi biaya tradisional biaya menghasilkan pembebanan biaya produk yang tidak akurat. Pengambilan keputusan oleh manajemen perusahaan yang berdasarkan informasi yang tidak akurat ini juga menjadi tidak tepat. Meskipun dalam penyajiannya, sistem akuntansi biaya konvensional menyajikan informasi biaya yang tidak akurat, sistem akuntansi biaya konvensional tetap dipakai karena memiliki sejumlah keunggulan, seperti mudah diterapkan, mudah diaudit dan sesuai dengan Prinsip Akuntansi yang Berlaku Umum.

\subsection{Pengertian Activity Based Costing (ABC)}

Menurut Carter (2009), metode ABC didefinisikan sebagai sebagai suatu sistem perhitungan biaya dimana tempat penampungan biaya overhead yang jumlahnya lebih dari satu dialokasikan menggunakan dasar yang mencakup satu atau lebih faktor yang tidak 
berkaitan dengan volume (Non-Volume Related Factor). Sedangkan menurut Tunggal (2011), metode ABC adalah costing sistem yang menjadikan aktivitas individu sebagai dasar cost object-nya. Metode ini mengkalkulasikan biaya dari setiap aktivitas yang dilakukan untuk memproduksi suatu produk atau jasa dan meng-Assign-nya kepada objek biaya (baik produk atau jasa).

Berdasarkan pengertian dari kedua ahli tersebut, dapat disimpulkan bahwa metode ABC adalah metode perhitungan biaya yang menghitung biaya secara individual dari setiap aktivitas untuk memproduksi sebuat produk dan membebankan biaya secara individu ke produk dengan memperhatikan satu atau lebih faktor yang tidak berkaitan dengan volume guna mengefisienkan biaya dan meningkatkan kontrol terhadap perusahaan .

\subsection{Struktur Pembebanan Activity Based Costing}

Di dalam penerapan $\mathrm{ABC}$, pembebanan biaya terhadap produk dilakukan berdasarkan aktivitas-aktivitas yang dilakukan untuk menghasilkan produk tersebut. Pembebanan terhadap produk dilakukan secara terperinci dan hanya terbatas pada aktivitas yang dilakukan untuk menghasilkan produk yang menikmati biaya yang dikeluarkan. Untuk itu, agar dapat menghitung biaya tersebut secara akurat, diperlukan data yang lengkap mengenai aktivitas dari kegiatan produksi. Aktivitas ini kemudian akan menjadi data yang diperlukan untuk membebankan biaya. Aktivitas-aktivitas tersebut berperan sebagai pemicu biaya (cost driver) dalam membebankan biaya ke produk.

Konsep ABC melakukan perhitungan biaya yang dibebankan dengan cara menelusuri biaya ke aktivitas-aktvitas yang dilakukan dan kemudian ke produk. ABC mengasumsikan bahwa aktivitas-aktivitas ini lah yang mengkonsumsi sumber daya kemudian menghasilkan biaya dan bukannya produk. Maka dari itu untuk menerapkan ABC diperlukan kejelasan akan akitivitas-aktivitas produksi yang dilakukan.

Menurut Carter (2009), ABC mengakui aktivitas, biaya aktivitas, dan pemicu aktivitas pada tingkatan agregasi (Level of Agregation) yang berbeda dalam satu lingkungan produksi. Empat tingkatan yang umumnya diidentifikasikan adalah unit, batch, produk, dan pabrik. Biaya Tingkat unit (Unit level cost) adalah biaya yang pasti akan meningkat ketika satu unit diproduksi. Biaya ini adalah satu-satunya tingkatan biaya yang dapat dibebankan secara proporsional dengan memperhatikan volume produksi. Adapun yang menjadi pemicu tingkatan biaya ini (unit level driver) adalah jumlah atau ukuran jumlah unit yang diproduksi atau dijual oleh perusahaan. Semua pemicu dari biaya tingkat unit bersifat proporsional terhadap volume output.

Biaya tingkat batch (batch level cost) adalah jumlah biaya yang disebabkan oleh jumlah batch yang diproduksi dan dijual. Yang dimaksud biaya batch disini adalah biaya yang dikeluarkan yang cenderung mencakup sebagian besar biaya pemasaran dan 
administrasi produksi. Yang menjadi pemicu biaya tingkat batch (batch level driver) adalah ukuran aktivitas yang bervariasi dengan jumlah batch yang diproduksi atau dijual.

Biaya tingkat produk (product level cost) adalah biaya yang terjadi untuk mendukung sejumlah produk berbeda yang dihasilkan. Biaya tersebut tidak harus dipengaruhi oleh produksi dan penjualan dari satu batch atau satu unit lebih banyak. Biaya tingkat produk merupakan biaya yang cenderung terjadi karena aktivitas untuk meningkatkan kualitas maupun memproduksi suatu produk seperti riset, pelatihan tenaga kerja, dan pergudangan. Yang menjadi pemicu biaya (product level driver) pada biaya tingkat produk adalah ukuran aktivitas yang bervariasi dengan jenis produk yang diproduksi dan dijual.

Biaya tingkat pabrik (plant level cost) adalah biaya yang dikeluarkan untuk memelihara kapasitas di lokasi produksi. Biaya yang dikeluarkan biasanya mencakup biaya asuransi, keamanan, pemeliharaan pabrik dan biaya pemeliharaan lainnya. Pemicu yang sering digunakan (plant level driver) untuk membebankan biaya tingkat pabrik adalah luas lantai bangunan pabrik.

\subsection{Pembebanan Biaya Overhead Berdasarkan Activiy Based Costing}

Menurut Mulyadi (2005), pembebanan biaya overhead dengan sistem ABC sering disebut dengan alokasi biaya overhead dua tahap (two-stage allocation), yaitu:

a. Tahap pertama

Mengumpulkan biaya dalam cost pool yang memiliki aktivitas yang homogen. Tahap ini terdiri dari empat langkah, yaitu:

1. Mengidentifikasi dan menggolongkan biaya ke dalam aktivitas.

2. Mengklasifikasikan aktivitas biaya ke dalam berbagai aktivitas, pada langkah ini biaya digolongkan ke dalam aktivitas yang terdiri dari 4 kategori yaitu :

i. Aktivitas berlevel unit (unit level activities)

ii. Aktivitas berlevel batch (batch level activities)

iii. Aktivitas berlevel produk (product level activities)

iv. Aktivitas berlevel fasilitas (facility level activities)

3. Mengidentifikasi cost driver.

4. Menentukan tarif/unit cost driver

b. Tahap kedua

Penelusuran dan pembebanan biaya aktivitas ke masing-masing produk yang menggunakan cost driver. Adapun pembebanan dilakukan dengan rumus:

BOP dibebankan $=$ tarif/unit cost driver $\mathrm{x}$ cost driver yang dipilih 


\subsection{Perbandingan Akuntansi Biaya Konvensional (Tradisional) dengan Activiy Based Costing}

Perbedaan antara akuntansi biaya konvensional dan Activiy Based Costing secara garis besar adalah pada saat pembebanan biaya overhead pabrik. Dalam hal ini perbedaan terjadi pada penggunaan pemicu biaya (Cost Driver). Pada sistem akuntansi biaya konvensional, cenderung hanya menggunakan satu pemicu biaya (Single Cost Driver) yaitu volume produksi. Sedangkan pada sistem Activiy Based Costing, digunakan lebih dari satu bahkan banyak pemicu biaya agar pembebanan yang dilakukan terhadap produk yang dihasilkan lebih akurat.

Menurut Carter (2009) terdapat beberapa perbedaan antara Activiy Based Costing dengan sistem akuntansi biaya tradisonal.

a. Perbedaan umum antara Activiy Based Costing dan sistem tradisional adalah homogenitas dari biaya dalam satu tempat penampungan biaya. Activiy Based Costing memerlukan identifikasi terhadap hubungan antara aktivias pemicu biaya dan tempat penampungan biaya (cost pool) yang tepat dan terperinci untuk mengumpulkan biaya yang kemudian akan dibebankan ke produk berdasarkan aktivitas pemicu biaya. Dan hasilnya dapat ditemukan bahwa terdapat hubungan yang logis antara tempat penampugan biaya dengan akivitas pemicu biaya. Sedangkan pada sistem tradisional, biaya dikumpulan langsung ke dalam penampungan biaya dan dibebanan berdasarkan single driver yang telah ditentukan oleh manajemen.

b. Semua sistem Activiy Based Costing merupakan perhtungan biaya dua tahap, sementara sistem konvensional bisa merupakan sistem perhitungan satu tahap atau dua tahap.

\section{METODE PENELITIAN}

Penelitian ini dilakukan dengan menggunakan metode studi kasus deskriptif. Metode studi kasus dipilih karena tujuan penelitian ini adalah untuk memberikan gambaran kehidupan nyata secara mendalam (Yin, 2009), terutama mengenai cara pembebanan biaya overhead dengan metode ABC. Secara lebih spesifik, Cooper \& Schindler (2011) menjelaskan bahwa penelitian deskriptif bertujuan untuk menjelaskan atau mengenalkan subjek penelitian dengan cara memberikan gambaran mengenai peristiwa, orang-orang atau kelompok permasalahan tertentu. Biasanya penelitian deskriptif dimaksudkan untuk menjawab pertanyaan tentang siapa, apa, kapan, di mana dan kadang-kadang bagaimana (Cooper \& Schindler, 2011). Oleh karena itu, demi mendapatkan pembahasan yang lebih komprehensif, metode studi kasus deskriptif dapat pula menyajikan informasi-informasi kuantitatif (Yin, 2009).

Untuk mendukung pembahasan mengenai penerapan metode $\mathrm{ABC}$ pada produkproduk PT. Sumber Djantin Sambas, diperlukan data yang lengkap guna menelusuri cost drivers yang sesuai. Oleh karena itu, penelitian ini mengumpulkan dokumen-dokumen keuangan berupa catatan maupun laporan mengenai kegiatan produksi. Sehubungan 
dengan dokumen keuangan ini, PT. Sumber Djantin Sambas sendiri memiliki pencatatan yang cukup lengkap yang memungkinkan perhitungan kembali biaya-biaya berdasarkan metode ABC berjalan dengan lancar. Pencatatan dilakukan oleh masing-masing departemen produksi juga sudah terperinci dengan baik sehingga memudahkan penulis untuk mengumpulkan data-data yang sesuai dan berguna bagi penelitian ini.

Selain data dokumen, sumber data untuk penelitian ini juga berasal dari wawancara dengan pimpinan pabrik. Tanya jawab diarahkan untuk mengumpulkan data seputar kegiatan peroduksi yang dilakukan di PT. Sumber Djantin unit Sambas. Adapun pertanyaan akan diajukan kepada staff dan kepala bagian produksi, pembukuan, dan manajer pabrik. Data dokumen dan hasil wawancara kemudian dianalisis dengan tahapan sebagai berikut:

a. Melakukan perhitungan harga pokok produk (HPP) dengan sistem akuntansi biaya konvensional. Rumus yang digunakan secara umum adalah :

HPP = Biaya Bahan Baku + Biaya Tenaga Kerja langsung + Biaya Overhead pabrik

b. Perhitungan harga pokok produk dengan menggunakan sistem Activiy Based Costing terdiri dari 2 tahap yaitu :

Tahap 1:

Mengidentifikasi dan mengklasifikasikan berbagai aktivitas dan biaya-biaya yang timbul. Kemudian tentukan cost driver dari aktivitas tersebut, dan kumpulkan biaya aktivitas yang sejenis ke dalam satu cost pool. Langkah berikutnya adalah menghitung tarif kelompok (cost pool). Menurut Hansen dan Mowen (2006) tarif kelompok dihitung dengan rumus :

$$
\text { Pool Rate }=\frac{\text { Biaya Kelompok }}{\text { Kapasitas Praktis Pergerakan Aktivitas }}
$$

Tahap 2 :

Setelah tarif kelompok diketahui, langkah selanjutnya adalah menentukan tarif biaya overhead yang akan dibebankan ke produk. Perhitungan dilakukan berdasarkan rumus:

BOP dibebankan $=$ tarif kelompok $\mathrm{x}$ unit cost driver yang digunakan

c. Membandingkan penetapan biaya produk menurut sistem akuntansi biaya konvensional dengan metode Activiy Based Costing. Analisis dilakukan dengan menghitung HPP kedua metode untuk dibandingkan. HPP dihitung dengan rumus :

Menurut sistem akuntansi biaya konvensional:

HPP = Biaya Bahan Baku + Biaya Tenaga Kerja Langsung + Biaya Overhead Pabrik Menurut Sistem ABC: 
HPP = Biaya Bahan Baku + Biaya Tenaga Kerja Langsung + Biaya Overhead Pabrik (Berdasarkan hasil yang didapat menurut rumus tahap 1 dan 2.)

Berdasarkan hasil yang didapat dari perhitungan HPP dengan metode konvensional dan Activiy Based Costing, maka dilihat perbandingan harga pokok yang didapat antara kedua metode. Metode yang tepat adalah metode yang menghasilkan pembebanan biaya yang lebih akurat terhadap produk sesuai dengan sumber daya yang dikonsumsi oleh produk.

\section{TEMUAN DAN PEMBAHASAN}

\subsection{Mengidentifikasi dan Menggolongkan Biaya ke Masing-Masing Aktivitas}

Perhitungan harga pokok produksi dengan menggunakan metode $\mathrm{ABC}$ dimulai dengan mengidentifikasi dan menggolongkan biaya ke dalam aktivitas. Pengidentifikasian aktivitas sebagai langkah awal guna menerapkan metode ABC. Adapun data untuk proses identifikasi aktivitas diperoleh dari hasil wawancara dengan kepala bagian pembukuan PT. Sumber Djantin dan kepala bagian produksi PT. Sumber Djantin Sambas serta laporan hasil produksi perusahaan. Aktivitas-aktivitas biaya dalam kegiatan produksi PT. Sumber Djantin Sambas, meliputi biaya bahan bakar, biaya asuransi, biaya astek, biaya produksi, biaya laboratorium, biaya bengkel, biaya alat pembantu, biaya pemeliharaan bangunan, biaya pemeliharaan mesin, biaya pemeliharaan inventaris, biaya pengolahan air limbah, biaya penyusutan bangunan, biaya penyusutan mesin, biaya penyusutan inventaris gudang.

Setelah mengidentifikasi aktivitas-aktivitas dalam kegiatan produksi PT. Sumber Djantin Sambas, biaya-biaya digolongkan ke dalam aktivitas yang terdiri dari 4 kategori, seperti yang disajikan di Tabel 1 .

Tabel 1. Penggolongan Biaya ke Dalam Aktivitas

\begin{tabular}{|c|c|c|}
\hline No & Penggolongan & Elemen Biaya \\
\hline 1 & $\begin{array}{l}\text { Biaya Tingkat Unit } \\
\text { (Unit Level Activity Cost) }\end{array}$ & $\begin{array}{l}\text { - Biaya Bahan Bakar } \\
\text { - Biaya Pengolahan Air Limbah }\end{array}$ \\
\hline 2 & $\begin{array}{l}\text { Biaya Tingkat Batch } \\
\text { (Batch Level Cost) }\end{array}$ & $\begin{array}{l}\text { - Iuran Produksi } \\
\text { - Biaya Asuransi } \\
\text { - Iuran Astek }\end{array}$ \\
\hline 3 & $\begin{array}{l}\text { Biaya Tingkat Produk } \\
\text { (Product Level Cost) }\end{array}$ & $\begin{array}{l}\text { - Biaya Laboratorium } \\
\text { - Biaya Alat Pembantu }\end{array}$ \\
\hline 4 & $\begin{array}{l}\text { Biaya Tingkat Pabrik } \\
\text { (Plant Level Cost) }\end{array}$ & $\begin{array}{l}\text { - Biaya Bengkel } \\
\text { - Biaya Pemeliharaan Bangunan } \\
\text { - Biaya Pemeliharaan Mesin } \\
\text { - Biaya Pemeliharaan Inventaris } \\
\text { - Biaya Penyusutan Bangunan } \\
\text { - Biaya Penyusutan Mesin } \\
\text { - Biaya Penyusutan Inventaris Gudang }\end{array}$ \\
\hline
\end{tabular}


Di dalam proses produksinya, aktivitas-aktivitas yang dilakukan terdiri dari 4 aktivitas utama. Berikut ini disajikan tabel yang memuat hasil alokasi atas biaya ke dalam aktivitas beserta jam operasional masing-masing aktivitas.

Tabel 2 Pengalokasian Biaya ke Dalam Aktivitas

\begin{tabular}{llcl}
\hline \multicolumn{1}{c}{ Aktivitas } & Alokasi Biaya & Jam Operasional \\
\hline Penggilingan & $8.157 .454 .318,03$ & 2.880 & jam \\
Dry House & $1.466 .253 .250,00$ & 8.760 & jam \\
Dryer & $3.010 .412 .492,00$ & 6.220 & jam \\
Finishing & $3.451 .414 .198,00$ & 6.716 & jam \\
\hline
\end{tabular}

Biaya yang telah dialokasikan ke dalam aktivitas-aktivitas utama seperti yang tersaji dalam Tabel 2 akan digunakan sebagai dasar perhitungan tarif per unit (Unit Cost). Tarif per unit ini akan dijadikan dasar perhitungan untuk menentukan Cost Driver dari sub-aktivitas dari masing-masing aktivitas utama tersebut.

\subsection{Menghitung Cost Driver untuk Masing-Masing Aktivitas}

Berdasarkan pengalokasian di Tabel 2, pengalokasian biaya untuk aktivitas penggilingan adalah sebesar Rp 8.157.454.318,03. Maka untuk menentukan tarif per unit (Unit Cost) dari aktivitas penggilingan akan dilakukan perhitungan sebagai berikut:

$$
\begin{aligned}
& \underset{\text { Penggilingan }}{\text { Tarif/ unit }}=\frac{\operatorname{Rp~8.157.454.318,03}}{2.880 \text { jam }}=\operatorname{Rp~2.832.449,42~Per~jam~} \\
& =\operatorname{Rp} 47.207,49 \text { Per Menit }
\end{aligned}
$$

Setelah unit cost di dapat maka tarif Cost Driver untuk masing-masing sub-aktivitas penggilingan akan disajikan di Tabel 3.

Tabel 3. Perhitungan Cost Driver

\begin{tabular}{clrrrr}
\hline $\begin{array}{c}\text { Aktivitas } \\
\text { Utama }\end{array}$ & \multicolumn{1}{c}{ Sub-Aktivitas } & $\begin{array}{c}\text { Unit Waktu } \\
\text { per Ton }\end{array}$ & Unit Cost & \multicolumn{2}{c}{ Cost Driver } \\
\hline \multirow{5}{*}{ Penggilingan } & Precleaning & 2 menit & $47.207,49$ & $94.414,98$ & Per Ton \\
& Pemecahan (Breaker) & 1 menit & $47.207,49$ & $47.207,49$ & Per Ton \\
& Peremahan (Hammermill) & 1 menit & $47.207,49$ & $47.207,49$ & Per Ton \\
& Penggilingan (Kilang) & 3 menit & $47.207,49$ & $141.622,47$ & Per Ton \\
\hline \multirow{2}{*}{ Dryer } & Breaker & 7 menit & $8.066,49$ & $56.465,43$ & Per Ton \\
& Dryer & 9,375 menit & $8.066,49$ & $75.623,34$ & Per Ton \\
\hline \multirow{5}{*}{ Finishing } & Pressing & 9,5 menit & $8.565,15$ & $81.368,93$ & Per Ton \\
& Palletizer & 16,7 menit & $8.565,15$ & $143.038,01$ & Per Ton \\
& Packing & 4,3 menit & $8.565,15$ & $36.830,15$ & Per Ton \\
& Uji Mutu & 6,7 menit & $8.565,15$ & $57.386,51$ & Per Ton \\
\hline
\end{tabular}


Aktivitas yang dilakukan di tahapan pengeringan pertama (Dry House), merupakan aktivitas produksi tunggal dimana produk setengah jadi berupa bahan Crumb basah (BCB) cukup digantungkan langsung ke kamar gantung (Dry House). Penggantungan dimaksudkan untuk memudahkan tahap pengeringan selanjutnya. Alokasi biaya untuk aktivitas di Dry House dialokasikan langsung berdasarkan jumlah bahan Crumb kering (BCK) yang dihasilkan. Untuk menghitung cost Driver dari aktivitas pengeringan pertama, yaitu dengan cara total biaya yang di alokasikan ke bagian Dry House dibagi total produksi Crumb Rubber. Perhitungan akan disajikan sebagai berikut:

$$
\text { Cost Driver }=\frac{\operatorname{Rp} 1.466 .253 .250,00}{15194,34 \text { Ton }}=\operatorname{Rp~96.499,96\quad Per~Ton~}
$$

Berdasarkan data yang diperoleh dari Tabel 2 maka tarif per unit (unit cost) aktivitas Dryer akan dihitung dengan cara sebagai berikut :

$$
\begin{aligned}
\text { Tarif/unit Dryer }=\frac{\operatorname{Rp} 3 \cdot 010.412 .492,00}{6.220 \mathrm{jam}} & =\operatorname{Rp} \quad 483.989,15 \text { Per Jam } \\
& =\operatorname{Rp} \quad 8.066,49 \text { Per Menit }
\end{aligned}
$$

Setelah unit cost di dapat maka tarif Cost Driver untuk masing-masing sub-aktivitas Dryer akan disajikan di Tabel 3.

Terakhir, berdasarkan data yang diperoleh dari Tabel 2, tarif per unit (Unit Cost) aktivitas Finishing akan dihitung dengan cara sebagai berikut :

$$
\begin{aligned}
\text { Tarif/unit } \quad=\frac{\operatorname{Rp} 3.451 .414 .198,00}{6.716 \mathrm{Jam}} & =\operatorname{Rp} 513.909,20 \quad \text { Per Jam } \\
\text { Finishing } & =\operatorname{Rp} 8.565,15 \text { Per Menit }
\end{aligned}
$$

Setelah unit cost di dapat maka tarif Cost Driver untuk masing-masing sub-aktivitas Finishing akan disajikan di Tabel 3.

Tabel 4. Pembebanan Biaya Overhead ke SIR 20

\begin{tabular}{clcrr}
\hline Aktivitas Utama & \multicolumn{1}{c}{ Sub-Aktivitas } & Produksi (Ton) & Cost Driver & \multicolumn{1}{c}{ Total Cost } \\
\hline \multirow{2}{*}{ Penggilingan } & $11.686,50$ & $94.414,98$ & $1.103 .380 .663,77$ \\
& Precleaning & $11.686,50$ & $47.207,49$ & $551.690 .331,89$ \\
& Pemecahan (Breaker) & $11.686,50$ & $47.207,49$ & $551.690 .331,89$ \\
& Peremahan (Hammermill) & $11.686,50$ & $141.622,47$ & $1.655 .070 .995,66$ \\
\hline \multirow{2}{*}{ Dry House } & Penggilingan (Kilang) & $11.686,50$ & $96.499,96$ & $1.127 .746 .782,54$ \\
\hline \multirow{2}{*}{ Dryer } & Breaker & $11.686,50$ & $56.465,43$ & $659.883 .247,70$ \\
& Dryer & $11.686,50$ & $75.623,34$ & $883.772 .162,91$ \\
\hline \multirow{2}{*}{ Finishing } & Pressing & $11.686,50$ & $81.368,93$ & $950.918 .000,45$ \\
& Palletizer & $11.686,50$ & $143.038,01$ & $1.671 .613 .703,87$ \\
& Packing & $11.686,50$ & $36.830,15$ & $430.415 .547,98$ \\
& Uji Mutu & $11.686,50$ & $57.386,51$ & $670.647 .449,12$ \\
\hline
\end{tabular}




\subsection{Pembebanan Biaya Overhead ke Produk}

Setelah Cost Driver untuk membebankan biaya Overhead didapat, langkah selanjutnya adalah menghitung biaya yang akan dibebankan ke dalam produk berdasarkan aktivitas yang dilakukan untuk menghasilkan produk. Adapun pembebanan biaya untuk produk SIR 20 akan disajikan secara lebih jelas di Tabel 4 dan untuk produk Compound Rubber akan disajikan di Tabel 5.

Tabel 5. Pembebanan Biaya Overhead ke Compound Rubber

\begin{tabular}{clrrr}
\hline $\begin{array}{c}\text { Aktivitas } \\
\text { Utama }\end{array}$ & \multicolumn{1}{c}{ Sub-Aktivitas } & $\begin{array}{c}\text { Produksi } \\
\text { (Ton) }\end{array}$ & Cost Driver & Total Cost \\
\hline \multirow{2}{*}{ Penggilingan } & Precleaning & $3.507,84$ & $94.414,98$ & $331.192 .643,44$ \\
& Pemecahan (Breaker) & $3.507,84$ & $47.207,49$ & $165.596 .321,72$ \\
& Peremahan (Hammermill) & $3.507,84$ & $47.207,49$ & $165.596 .321,72$ \\
& Penggilingan (Kilang) & $3.507,84$ & $141.622,47$ & $496.788 .965,16$ \\
\hline \multirow{2}{*}{ Dry House } & Breaker & $3.507,84$ & $96.499,96$ & $338.506 .419,69$ \\
\hline \multirow{2}{*}{ Dryer } & Dryer & $3.507,84$ & $56.465,43$ & $198.071 .693,97$ \\
& Pressing & $3.507,84$ & $75.623,34$ & $265.274 .576,99$ \\
\hline \multirow{2}{*}{ Finishing } & Palletizer & $3.507,84$ & $81.368,93$ & $285.429 .187,41$ \\
& Packing & $3.507,84$ & $143.038,01$ & $501.754 .453,00$ \\
& Uji Mutu & $3.507,84$ & $36.830,15$ & $129.194 .273,38$ \\
& \multicolumn{2}{c}{ Total Biaya Overhead } \\
\hline \multirow{2}{*}{} & $3.507,84$ & $57.386,51$ & $201.302 .695,24$ \\
\hline
\end{tabular}

\subsection{Menghitung Harga Pokok Produksi}

Setelah biaya overhead untuk masing-masing produk diketahui, langkah berikutnya adalah menentukan harga pokok produksi dari masing-masing produk dengan menggunakan metode ABC. Harga pokok produksi didapat dengan cara menjumlahkan biaya bahan baku, biaya tenaga kerja, dan biaya Overhead kemudian ditambah dengan persediaan barang setengah jadi awal dan dikurang dengan persediaan barang setengah jadi akhir. Untuk biaya tenaga kerja dan bahan baku, perhitungan tidak perlu dilakukan karena dapat ditelusuri langsung dan dapat langsung dibebankan ke dalam produk. Harga pokok produksi masing-masing produk akan disajikan di Tabel 6.

\subsection{Perbandingan Perhitungan Harga Pokok Produksi dengan Metode ABC dengan Metode Tradisional yang Digunakan oleh Perusahaan.}

Setelah harga pokok produksi kedua produk didapat dengan menggunakan metode Activity Based Costing, maka langkah berikutnya adalah membandingkan hasil perhitungan menurut metode Activity Based Costing dengan metode tradisional yang digunakan oleh perusahaan. Selama ini, PT. Sumber Djantin unit Sambas menggunakan metode tradisional dalam menentukan harga pokok produksi atas produk yang dihasilkan. 
Perhitungan dilakukan dengan cara menjumlahkan seluruh biaya produksi dan kemudian ditambah dengan jumlah barang dalam proses awal dan dikurangi dengan jumlah barang dalam proses akhir.

Tabel 6. Harga Pokok Produksi dengan Metode ABC

\begin{tabular}{lccccr}
\hline & \multicolumn{2}{c}{ SIR 20 } & \multicolumn{2}{c}{ Compound Rubber } \\
\hline Work in Process (awal) & $\mathrm{Rp}$ & $28.361 .139 .035,98$ & $\mathrm{Rp}$ & $8.211 .045 .245,02$ \\
Bahan Baku & & & & \\
- Lump & $\mathrm{Rp}$ & $90.960 .389 .852,68$ & $\mathrm{Rp}$ & $26.334 .622 .020,58$ \\
- sit & $\mathrm{Rp}$ & $245.865 .342 .831,53$ & $\mathrm{Rp}$ & $71.182 .312 .234,09$ \\
- Stearic Acid & & - & $\mathrm{Rp}$ & $240.291 .527,00$ \\
- Synthetic rubber & & - & $\mathrm{Rp}$ & $1.844 .785 .871,35$ \\
Biaya Tenaga Kerja & $\mathrm{Rp}$ & $4.052 .343 .065,03$ & $\mathrm{Rp}$ & $1.216 .358 .284,97$ \\
Overhead & $\mathrm{Rp}$ & $10.256 .829 .217,74$ & $\mathrm{Rp}$ & $3.078 .707 .551,72$ \\
Work in Process (akhir) & $\mathrm{Rp}(40.898 .580 .829,57)$ & $\mathrm{Rp}(11.840 .853 .684,43)$ \\
\hline Harga Pokok Produksi & $\mathrm{Rp}$ & $338.597 .463 .173,40$ & $\mathrm{Rp}$ & $100.267 .269 .050,29$ \\
\hline
\end{tabular}

Adapun alokasi untuk biaya Overhead, PT Sumber Djantin unit Sambas tidak memisahkan antara Compound Rubber dengan SIR 20. Alokasi dilakukan secara langsung dengan mengunakan jumlah produksi sebagai patokan alokasi harga. Perhitungan untuk biaya Overhead PT Sumber Djantin Sambas akan diajikan pada Tabel 7.

Tabel 7. Perhitungan Biaya Overhead dengan Metode Tradisional

\begin{tabular}{lccr}
\hline & Jumlah Produksi (Kg) & \multicolumn{2}{c}{ Biaya Overhead } \\
\hline SIR 20 & 11.686 .500 & $\mathrm{Rp}$ & $12.371 .948 .772,14$ \\
Compound Rubber & 3.507 .840 & $\mathrm{Rp}$ & $3.713 .585 .485,89$ \\
Total & 15.194 .340 & $\mathrm{Rp}$ & $16.085 .534 .258,03$ \\
\hline
\end{tabular}

Setelah biaya Overhead didapat, maka perhitungan harga pokok produksi dengan metode tradisonal akan disajikan di Tabel 8.

Tabel 8. Perhitungan Harga Pokok Produksi dengan Metode Tradisional

\begin{tabular}{lcccc}
\hline & \multicolumn{2}{c}{ SIR 20 } & \multicolumn{2}{c}{ Compound Rubber } \\
\hline Work in Process (awal) & $\mathrm{Rp}$ & $28.361 .139 .035,98$ & $\mathrm{Rp}$ & $8.211 .045 .245,02$ \\
Bahan Baku & & & & \\
- Lump & $\mathrm{Rp}$ & $90.960 .389 .852,68$ & $\mathrm{Rp}$ & $26.334 .622 .020,58$ \\
- sit & $\mathrm{Rp}$ & $245.865 .342 .831,53$ & $\mathrm{Rp}$ & $71.182 .312 .234,09$ \\
- Stearic Acid & & - & $\mathrm{Rp}$ & $240.291 .527,00$ \\
- Synthetic rubber & & - & $\mathrm{Rp}$ & $1.844 .785 .871,35$ \\
Biaya Tenaga Kerja & $\mathrm{Rp}$ & $4.052 .343 .065,03$ & $\mathrm{Rp}$ & $1.216 .358 .284,97$ \\
Overhead & $\mathrm{Rp}$ & $12.371 .948 .772,14$ & $\mathrm{Rp}$ & $3.713 .585 .485,89$ \\
Work in Process (akhir) & $\mathrm{Rp}(40.898 .580 .829,57)$ & $\mathrm{Rp}(11.840 .853 .684,43)$ \\
\hline \multicolumn{1}{c}{ Harga Pokok Produksi } & $\mathrm{Rp} 340.712 .582 .727,80$ & $\mathrm{Rp}$ & $100.902 .146 .984,46$ \\
\hline
\end{tabular}


Setelah harga pokok penjualan didapat dengan menggunakan metode ABC dan metode tradisional, langkah selanjutnya adalah membandingkan hasil dari kedua metode tersebut. Perbandingan perhitungan akan disajikan secara jelas di Tabel 9.

\section{Tabel 9. Perbandingan Harga Pokok Produksi dengan Menggunakan Metode Tradisional dan Activity Based Costing}

\begin{tabular}{llrrr}
\hline & \multicolumn{1}{c}{ SIR 20 } & \multicolumn{2}{c}{ Compound Rubber } \\
\hline Tradisional & $\mathrm{Rp}$ & $340.712 .582 .727,80$ & $\mathrm{Rp}$ & $100.902 .146 .984,46$ \\
ABC & $\mathrm{Rp}$ & $338.597 .463 .173,40$ & $\mathrm{Rp}$ & $100.267 .269 .050,29$ \\
\hline Selisih & $\mathrm{Rp}$ & $2.115 .119 .554,40$ & $\mathrm{Rp}$ & $634,877,934,17$ \\
\hline
\end{tabular}

Dari data yang telah diolah maka didapatkan perbandingan harga pokok produksi untuk masing-masing produk dengan menggunakan metode tradisional dan ABC. Dari Tabel 9 dapat terlihat bahwa terdapat perbedaan yang cukup besar antara kedua metode pada produk SIR 20. Selisih biaya yang dibebankan oleh masing-masing metode adalah sebesar Rp2.749.997.488,57 dimana biaya yang dibebankan dengan menggunakan metode ABC lebih kecil dibandingkan dengan metode tradisional. Dengan demikian apabila perusahaan menerapkan metode $\mathrm{ABC}$, maka perusahaan dapat menghilangkan efek distorsi biaya produksi yang sering terjadi pada metode tradisional sebesar Rp2.749.997.488,57. Selain itu penerapan metode ABC juga memberikan tingkat keakuratan (Accuracy) pengalokasian biaya yang lebih tinggi karena pengalokasian biaya berdasarkan aktivitas yang dikonsumsi oleh masing-masing produk.

\section{KESIMPULAN}

Dari hasil pengumpulan informasi dan penelusuran yang dilakukan guna menghitung harga pokok produksi pada PT. Sumber Djantin Sambas, maka dapat ditarik kesimpulan sebagai berikut. Pertama, proses perhitungan harga pokok produksi dengan menggunakan metode $\mathrm{ABC}$ memerlukan data yang lengkap. Data-data tersebut juga perlu diolah sedemikian rupa dan dikumpulkan secara terperinci guna mendapatkan hasil yang akurat.

Kedua, dari hasil penelitian dan perhitungan dengan metode $\mathrm{ABC}$ yang telah dilakukan, diperoleh harga pokok produksi untuk produk SIR 20 adalah sebesar Rp 338.597.463.173.40 dan untuk produk Compound Rubber adalah sebesar Rp 100.267.269.050.29. Sedangkan perhitungan dengan metode tradisional seperti yang digunakan oleh perusahaan diketahui bahwa harga pokok produksi untuk produk SIR 20 adalah sebesar Rp 340.712.582.727.80 dan untuk produk Compound Rubber adalah sebesar Rp 100.902.146.984.46. Terdapat selisish sebesar Rp 2.115.119.554,40 untuk produk SIR 20 dan sebesar Rp. 634.877.934,17 untuk produk Compound Rubber. Total selisih dari kedua metode perhitungan adalah sebesar Rp. 2.749.997.488,57 dimana harga 
pokok produksi dengan metode $\mathrm{ABC}$ lebih rendah bila dibandingkan dengan harga pokok produksi dengan menggunakan metode tradisional seperti yang digunakan oleh perusahaan.

Akhirnya, selisih yang terjadi antara metode ABC dan metode tradisional terjadi akibat perbedaan pembebanan tarif overhead. Pembebanan tarif overhead dengan menggunakan metode $\mathrm{ABC}$ cenderung lebih tepat karena pembebanan dilakukan berdasarkan aktivitas-aktivitas pengkonsumsi biaya yang dilakukan untuk menghasilkan suatu produk. Kesimpulan yang ditarik dalam penelitian ini hanya terbatas pada PT. Sumber Djantin Sambas dan perusahaan karet yang memiliki karakteristik yang sama dengan perusahaan kasus. Selain itu, penelitian ini juga hanya analisis data biaya selama setahun. Hal ini tentu tidak dapat mencakup pembahasan mengenai efek perubahan struktur biaya dan aktivitas dengan berjalannya waktu serta tidak mampu membahas efek dari kurva pembelajaran dan kurva pengalaman. Penelitian selanjutnya diharapkan dapat mereplikasi penelitian ini pada perusahaan kasus lainnya dengan bidang usaha yang berbeda serta melakukan analisis data keuangan dari perusahaan kasus selama beberapa tahun sehingga dapat memperkaya pemahaman mengenai aplikasi metode $\mathrm{ABC}$ di dunia bisnis.

\section{DAFTAR PUSTAKA}

Atkinson, A. A., Kaplan, R. S., Matsumura, E. M., \& Young, S. M. (2012). Management Accounting: Information for Decision Making and Strategy Execution (6 ed.). Harlow: Pearson Education.

Carter, W. K. (2009). Cost Accounting (14 ed.). Manson, USA: Cengage.

Cooper, D. R., \& Schindler, P. S. (2011). Business Research Methods (11th ed.). New York: McGraw Hill/Irwin.

Hansen, D. R., \& Mowen, M. M. (2007). Managerial Accounting (8 ed.). Mason, USA: South-Western Cengage.

Hilton, R. W., \& Platt, D. E. (2015). Managerial Accounting: Creating Value in Dynamic Business Environment (Global Edition) (10 ed.). Singapore: McGraw-Hill.

Horngren, C. T., Datar, S. M., \& Rajan, M. V. (2012). Cost Accounting: A Managerial Emphasis (14 ed.). Harlow: Pearson Education.

Martusa, R., \& Adie, A. F. (2011). Peranan Activity-Based Costing System dalam Perhitungan Harga Pokok Produksi Kain yang Sebenarnya untuk Penetapan Harga Jual: Studi Kasus pada PT Panca Mitra Sandang Indah, Akurat Jurnal Ilmiah 
Akuntansi, 4(2), Diakses dari http://id.portalgaruda.org/index.php?ref=browse $\& \bmod =$ viewarticle $\&$ article $=72257$

Mulyadi (2005). Akuntansi Biaya (Ed. 5). Yogyakarta: Aditya Media.

Panggiarti, E. K. (2010). Penerapan Activity-Based Costing (ABC) pada Sector Usaha Mikro, Majalah Ilmiah Dinamika, 3(2), 132-144.

Tunggal, A. W. (2011). Dasar-dasar Akuntansi Biaya dan Manajemen. Jakarta: Harvarindo.

Yin, R. K. (2009). Case Study Research: Design and Methods (4th ed.). California: SAGE. 


\section{LAMPIRAN}

\begin{tabular}{|c|c|c|}
\hline \multicolumn{3}{|c|}{ PT. SUMBER DJANTIN SAMBAS } \\
\hline \multicolumn{3}{|c|}{ LAPORAN HARGA POKOK PRODUKSI } \\
\hline \multicolumn{3}{|c|}{ UNTUK TAHUN YANG BERAKHIR 31 DESEMBER 2011 DAN 2012} \\
\hline & 2011 & 2012 \\
\hline \multicolumn{3}{|l|}{ HARGA POKOK PRODUKSI } \\
\hline \multicolumn{3}{|l|}{ Bahan Baku } \\
\hline Persediaan Awal & $87,166,206,264.00$ & $3,049,186,477.00$ \\
\hline Pembelian Bahan & $706,149,069,493.36$ & $438,023,363,740.23$ \\
\hline Persediaan akhir bahan baku & $3,049,186,477.00$ & $4,644,805,880.00$ \\
\hline & & - \\
\hline Jumlah pemakaian bahan baku & $790,266,089,280.36$ & $436,427,744,337.23$ \\
\hline & 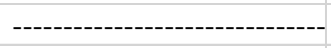 & 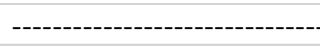 \\
\hline \multicolumn{3}{|l|}{ Biaya Gaji dan Upah Langsung } \\
\hline GajI Buruh & $372,271,250.00$ & $366,862,200.00$ \\
\hline Upah Harian & $570,199,750.00$ & $690,245,300.00$ \\
\hline Upah Lembur & $239,170,700.00$ & $162,265,450.00$ \\
\hline Upah Press & $1,063,355,350.00$ & $865,374,000.00$ \\
\hline Upah Hammermil & $373,660,700.00$ & $337,996,850.00$ \\
\hline Upah Dry House & $804,961,600.00$ & $751,210,800.00$ \\
\hline Upah Giling & $602,309,850.00$ & $535,769,000.00$ \\
\hline Upah Bongkar & $646,641,500.00$ & $648,888,000.00$ \\
\hline Tunjangan Hari Raya & $502,880,000.00$ & $477,610,000.00$ \\
\hline Tunjangan Buruh & $447,156,300.00$ & $182,629,750.00$ \\
\hline Biaya Pesangon & $174,150,000.00$ & $249,850,000.00$ \\
\hline & & \\
\hline Jumlah Biaya Gaji dan Upah Langsung & $5,796,757,000.00$ & $5,268,701,350.00$ \\
\hline & 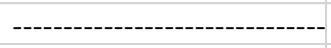 & 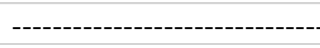 \\
\hline \multicolumn{3}{|c|}{ Biaya Produksi Lain - Lain (Overhead Pabrik) } \\
\hline Bahan Bakar & $10,727,569,618.00$ & $11,007,355,250.00$ \\
\hline Biaya Asuransi & $810,059,418.10$ & $418,560,523.00$ \\
\hline Iuran Astek & $130,144,937.00$ & $190,653,914.00$ \\
\hline Iuran Produksi & $105,777,000.00$ & $67,684,000.00$ \\
\hline Biaya Laboratorium & $107,096,500.00$ & $86,280,250.00$ \\
\hline Biaya Bengkel & $214,451,775.00$ & $162,176,000.00$ \\
\hline Biaya Alat Pembantu & $93,480,575.00$ & $86,581,920.00$ \\
\hline Biaya Pemeliharaan Bangunan & $605,512,127.27$ & $1,021,004,570.00$ \\
\hline Biaya Pemeliharaan Mesin & $1,260,581,264.32$ & $1,303,832,433.48$ \\
\hline Biaya Pemeliharaan Inventaris & $169,578,805.73$ & $23,681,750.00$ \\
\hline Biaya Pengolahan Air Limbah & $180,038,350.00$ & $188,374,680.00$ \\
\hline Biaya Penyusutan Bangunan & $325,503,807.00$ & $398,119,557.00$ \\
\hline Biaya Penyusutan Mesin & $1,327,800,985.45$ & $1,111,667,271.55$ \\
\hline Biaya Penyusutan inventaris Gudang & $17,890,751.00$ & $19,562,139.00$ \\
\hline & --------------------------------- & -------------------------------. \\
\hline Jumlah Biaya Produksi lain-lain & $16,075,485,913.87$ & $16,085,534,258.03$ \\
\hline & 更 & 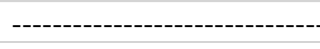 \\
\hline Jumlah Biaya Produksi & $21,872,242,913.87$ & $21,354,235,608.03$ \\
\hline & ------------------------------- & 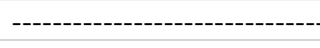 \\
\hline \multicolumn{3}{|l|}{ Persediaan Barang dalam Proses } \\
\hline Pesediaan awal tahun & $61,599,403,587.00$ & $36,572,184,281.00$ \\
\hline Persediaan akhir tahun & $36,572,184,281.00$ & $52,739,434,514.00$ \\
\hline & 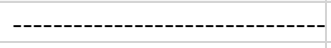 & 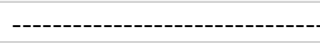 \\
\hline \multirow[t]{2}{*}{ HARGA POKOK PRODUKSI } & $837,165,551,500.23$ & $441,614,729,712.26$ \\
\hline & $=================$ & $=================$ \\
\hline
\end{tabular}

